\title{
Appraisal of Higher Education Academic Staff
}

\section{Rukhsana Zia}

\begin{abstract}
The Annual Confidential Report is a government document and is used by all government departments. The document is used for all employees of Grade 16 and above. The same document is used for the teaching staff as well. The inefficiency of the document to present an appropriate appraisal of scholarship characteristics of the higher education academic staff is evident. This study will focus on identifying various factors that ought to be assessed to provide information about the performance of the teaching staff and help formulate an effective format to achieve the objectives of appraisal.
\end{abstract}

\section{Introduction}

In Pakistan the teaching staff of government higher education (HE) institutions are annually reviewed by the head of the institution. The appraisal form is called the Annual Confidential Report. It has a standard format, and is applicable to all government officers Grade 16 and above. The form lists characteristics such as Personal Qualities (intelligence, confidence, appearance etc.); Attitudes (knowledge and attitude towards Islam, foresight, financial responsibility, judgement etc.); Proficiency on job (power of written and oral expression, knowledge of work, analytical ability, supervision and guidance etc.), which do not focus on the specific tasks related to teaching and learning. This limits the role of assessment and does not introduce the concept of professional development as an intrinsic part of the process. Furthermore, the head of the institution engages in a confidential procedure of assessing the academic faculty. This results in the assessment being regarded as threatening rather than a valuable way of indicating the strengths of the teaching staff. Education personnel are, by and large, critical of the validity of the ACR as an assessment document and demand changes in its format (Zia 1994 p 377). Without a formal appraisal system,

"...appraisal is covert, secret, liable to be based on impulse or prejudice, incorrect or inadequate information"

(Turner 1981)

Turner criticises it as management failure if a well thought out system of appraisal has not been produced which he believes is the right of every staff member. It is not difficult to translate the above to the system in practice in most HE institutions of Pakistan. 


\section{Limitations of the Study}

There are many roles at various levels of the service structure that are discharged by the Higher Education Academic Staff (HEAS). In some cases these might pertain to purely management/administration related posts. The appraisal would require different or additional factors for their assessment. This would be true, for example, in the case of a department head or the institutional head. This study focuses on the appraisal of teaching faculty.

The format provided should not be considered as the only way to assess the AS. It will provide a guideline that can be reformulated according to the needs of the individual institutions, or by the employing authority for the institutions.

Different ranks of teachers usually require different standards of competencies/scholarship at different institutions. It is hoped that each institution/employing authority will develop its own criteria for the different ranks which will then have to be reviewed accordingly.

For the sake of this study, words like review, appraisal, evaluation, assessment are considered synonymous. It does not need to be clarified that all can have subtle differences.

Appraisal of the academic faculty will need to be done at various levels for optimal effectiveness. It can be self-appraisal, peer appraisal, appraisal by students, upward appraisal and line appraisal. This study focuses on line appraisal, whereby appraisal of the faculty is done by the "boss", in this specific case, the head of the institution.

Various factors contribute to and result from a natural progression of assessment procedures as underlined in this study. The discussion of these is beyond the scope of this paper. (e.g. incentives for improvement, rewards for improvement and so on).

Appraisal when stated as areas of responsibility to be assessed, needs to be established as a scheme within a systematic process. This study does not delve into the procedural details of management for the process.

\section{Significance of the Study}

As stated earlier, the ACR form does not assess the education personnel, especially teaching faculty, as per the competencies required for teaching in a $\mathrm{HE}$ institution. This study will delineate the role of teachers in 
HE institutions and thus provide direction to assessment in the required areas of responsibility suited to their job.

The scholarship characteristics delineated in the study will provide a concise picture of excellence in areas of responsibility relevant to the role of the AS and provide a listing of characteristics that will give a valid exposition of their teaching capability.

It will provide a powerful fool for all the teaching faculty in HEAS, who can discover, amongst other things:

What is expected of them

How well they are doing

How they can do better

How they can develop their careers

(Everard 1986)

Feedback on performance is an essential element for attaining and maintaining excellence in scholarship of the HEAS. The guidelines provided in this study will define a feedback criteria which if used systematically, and in an environment of empathy, communication and participation (Kirkpatrick, 1985) will provide a thorough and effective assessment. In fact such a feedback system established on a regular basis is a part of the institution's normal management function and should be introduced at the earliest.

Appraisal, as suggested by this study, over a period of time will motivate the HEAS towards their professional development and to engage in developmental activities in the identified areas of responsibility. James and Newman (1985), identified several main aims of staff appraisal which emphasise the promotion of staff development, communication, assistance in management, motivation, improved efficiency and quality, self-evaluation, reviewing performance to identify strengths and weaknesses, and identifying in-service training needs: All these changes and more is hoped to come about as a result of the introduction of such an appraisal system.

\section{What is Faculty Appraisal?}

Faculty appraisal, conventionally speaking, is a system in which the head of the institution or another designated person meets with a member of the faculty to review the staff member's activities during the past year and to exchange views over possible developments for the next year 
(Greenaway and Mortimer 1979 pp 57-79). This reflects a two-way discourse and does away with the negative and punitive connotations implicated by the confidentiality of the procedure currently in practice, basically in government education institutions. Faculty appraisal can be and should be seen as a valuable way of providing clarification and feedback to the concerned staff members on the performance of their roles and responsibilities, its three main aims can be stated as:

1. to assess past performance

2. to assess training and development needs

3. to assess future potential

(Baron 1978)

The main objectives of the faculty appraisal scheme, as reflected in the following pages will be to:

- identify the strengths and weaknesses of the staff members

- assess their performance and assist them in the development of their careers,

- create an incentive to improve their performance,

- above all, it will help to identify changes in the operation of the HE institution which would enable the individual faculty to improve their performance.

\section{Responsibilities of the Teaching Faculty in the Institutions}

"A community of scholars" is the classic definition of a university (Brown and Thornton $1971 \mathrm{p}$ 44) which can apply to any HE institution. The faculties of colleges and universities, by and large, see themselves as scholars, that is, they conceive that their efforts should be devoted to the extension, through research, of understanding in all areas of knowledge. The scholar feels the responsibility to identify, to recruit and to guide those who will continue research in the future. In fact he/she accepts the education of scholars in his field of study as an integral purpose. Another equally important aspect is the education of the non-specialist, which he/she hopes will provide a trained elite from which the nation's leadership may come. As such the role of a HEAS revolves around "scholarship". Scholarship is the possession of extensive and profound knowledge of a subject along with being up-to-date with developments in that field. HE is being increasingly identified with emphasis in research, translated to HEAS it connotes both 
teaching and research capability. Thus, scholarship is an umbrella term used for responsibilities imperative for the HE teaching faculty in the following areas:

1. teaching

2. research/creative activities

3. institutional service/administrative, managerial activities.....

(The Faculty Handbook, Iowa State University, 1998 p 11)

The broad continuum of scholarship is described in Appendix-A. The table describes the parameters to be used for judging the scholarly nature of a faculty member's achievements in appraisal/evaluation reviews. In certain fields journals are the traditional method of documenting scholarship, in others, exhibitions and performances are the appropriate form. In others new technologies will create new media. In certain cases, there might be no documentation by peers, nevertheless, both documented and undocumented scholarship provides a holistic portrayal of the faculty's academic work.

Brown and Thornton (1971 pp 43-52) state the professional responsibilities of the college teacher, which can be translated to all $\mathrm{HE}$ teachers, as responsibility to:

1. himself

2. his colleagues

3. his discipline

4. the administration

5. students

All the above is to be placed in an environment of academic freedom with rights, reasonable rewards and so on.

For the sake of this study the areas of responsibility specified in The Faculty Handbook, Iowa State University are used as a guideline, with appropriate modifications where necessary.

\section{Areas of Responsibility and the Related Activities/Indicators}

This study has identified three areas of responsibility for the faculty of $\mathrm{HE}$ institutions. The following pages will try to provide examples of activities that may be documented in each area of faculty responsibility. 
116 The Lahore Journal of Economics, Vol.3, No.2

Each institution can state additional areas of responsibility in keeping with their mission statement.

\section{Teaching}

Teaching is a scholarly and dynamic endeavor and covers a broad range of activities. The HEAS have significant teaching responsibilities and quality of teaching is a major concern for their evaluation.

In most countries around the world, the conventional viewpoint holds that the ideal $\mathrm{HE}$ teacher holds the terminal/Ph.D. degree in the concerned discipline. But concept of scholarship propounded for HEAS indicates that a "doctorate shows nothing about the teaching ability" (Brown and Thornton $1971 \mathrm{p} \mathrm{42)}$. Understanding, depth of knowledge is an essential quality for a HEAS but it is, by itself, not enough.

Undoubtedly, effectiveness in teaching is essential, HEAS must demonstrate not only a command over their subject matter but show a continuous growth in the subject field and an ability to create and promote an environment that promotes optimal student learning. In other words excellence in teaching is related to efficient student learning. It needs to be realised that different expressions of the term "effective teaching" exist and have to be accepted. Some teachers may exhibit a command over lecture giving, others may promote collaborative learning, while still others may be adept at organised group discussions. Good teaching can mean excellence in different pedagogical skills.

The activities/indicators that exhibit excellence in teaching (for undergraduate and post graduate classes) are:

- command over subject matter including knowledge of recent developments,

- knowledge and use of appropriate teaching techniques and technology,

- presentation of subject matter with conviction,

- presentation of material in a way that promotes the learning process,

- well-written design of syllabi and course planning,

- good relationship with students, that is, 
accessibility

ability to enthuse, guide, inspire and involve students

giving feedback to students

concern and respect for students

making students aware of the relationship of the subject to other fields

- excellence in advising, that is,

interact constructively with advisees

be informed of current policies and procedures

aid students in the use of the institution's resources

assist students in learning to make intelligent choices

be knowledgeable about curricular and extracurricular activities

- skillful as an examiner, that is, in evaluation/assessment procedures

- significant contributions to professional associations

- overall assessment of ability and attitude as a teacher

- competence in postgraduate supervision (Beard and Hartley pp 261-267)

ability and willingness to motivate research students

relationship with research students (helpfulness and quality of feedback)

ability to identify research projects

management and supervision of research projects

completion rate

relationship with co-operating organisations

thoroughness as examiner

overall assessment of ability and attitude as a research supervisor 
118 The Lahore Journal of Economics, Vol.3, No.2

- ability for other teaching activities such as short courses in the discipline/related areas

ability to attract sponsors, course members

ability to design courses and plan programmes

preparation and planning of course materials

knowledge and use of appropriate instructional strategies

overall assessment of ability and attitude in this field

\section{Research/creative Activities}

It is commonly accepted all over the world, and increasingly being propounded in Pakistan that research is a very significant part of a teacher's role in HE. In fact in the western world, HEAS face the conflict between the demands of teaching and research (Beard et al $1978 \mathrm{p} \mathrm{88)}$. Both are equally important and each institution and each department within the institution will need to identify the desired balance between the two. In an appraisal system, teaching and research activities need to be considered in a manner that the faculty is motivated towards enhanced achievement in both.

HEAS who engage in research/creative activities are expected to make original contributions that are appropriate to their chosen area of specialisation, are respected by peers within and outside the university/ college. The following are some of the indicators for research competence, but it should be realised that all the above may not be equally relevant to all members of staff in different faculties. (In Pakistan the difference may be greater from institution to institution due to lack of resources at the disposal of the staff for research/creative activities):

- Amount of research/creative/artistic activity over the past year

- number of publications

- quality of research and publications

- ability to attract research students

- guidance of research projects of students

- ability to identify original and feasible research issues

- design and management of research projects 
- ability to disseminate results of research/creative activity

- peer group evaluation, that is, invitations to conferences and to give papers and so on, respect by peers in and outside the country

- industrial and commercial links

- overall assessment of ability and attitude as researcher and research leader

- awareness of new developments in the area of speciality and related fields

- membership in related professional/scholarly societies and organisations

- other relevant aspects, if applicable

\section{Institutional Service/Managerial/Administrative Activities}

All HEAS are expected to play a vital role in the functioning of the institution at all levels, by participating in governance and policy formulation or by carrying out administrative responsibilities. this shows the involvement in institutional service and forms an important aspect to be assessed for the faculty member's performance. The listing can include membership on various college/university committees and organisations with clear indication of the staff member's role.

The following criteria need to be considered for appraisal:

- willingness to assume administrative responsibilities

- amount and range of involvement in such activities

- thoroughness and reliability of administrative work, that is, accuracy to meet deadlines

- ability to manage such programmes

- administrative ability, such as innovation, initiative

- communication skills/quality of interpersonal relationships

- supervision of technical/clerical/administrative staff 
- overall assessment of ability and attitude as administrator and manager.

\section{Other Relevant Activities}

Most of the activities performed by the faculty of HE institutions have been covered in the above paragraphs. There can be other activities, which contribute towards scholarship of the HEAS and need to be considered. These activities are listed below:

- contribution to departmental activities, membership on departmental committees

- contribution to extra-curricular activities, such as contact with students, visitors

- representative duties on behalf of the institution such as, public boards, councils

- unpaid service to local community or local industry

- any other contribution to profession, national bodies, international activities

- other relevant activities

- overall assessment of ability and attitude regarding extracurricular activities.

\section{Conclusions}

The ACR form currently in use in government institutions of HE is deficient in delivering the objectives of appraisal of the AS. In the light of the above documentation it is hoped that it will be modified to meet the scholarship level expected of the teaching faculty. More importantly, the confidential nature of the assessment has to be converted to a two-way discourse and demands immediate attention.

The preceding pages have delineated the role/areas of responsibility for the HEAS and provided a guideline of indicators that can help to assess them efficiently and effectively. As such, the indicators it offers stand valid for most institutions of $\mathrm{HE}$ in Pakistan. It will of course, need further research to polish it to the needs of the individual institutions. Detailed attention will also be required to establish an overall scheme with wellplanned management procedures. 


\section{Appendix-A}

\section{The Nature of Scholarship}

\begin{tabular}{|c|c|c|c|c|}
\hline $\begin{array}{l}\text { NATURE OF } \\
\text { SCHOLARSHIP }\end{array}$ & $\begin{array}{c}\text { AUDIENCES } \\
\text { FOR } \\
\text { SCHOLAR- } \\
\text { SHIP } \\
\end{array}$ & $\begin{array}{c}\text { MEANS OF } \\
\text { COMMUNICA- } \\
\text { TION }\end{array}$ & $\begin{array}{l}\text { CRITERIA FOR } \\
\text { VALIDATION }\end{array}$ & $\begin{array}{c}\text { MEANS OF } \\
\text { DOCUMENTA- } \\
\text { TION }\end{array}$ \\
\hline $\begin{array}{l}\text { Develops and } \\
\text { communicates } \\
\text { new } \\
\text { understanding } \\
\text { and insights. } \\
\text { Generates, } \\
\text { synthesises, } \\
\text { interprets, } \\
\text { critically } \\
\text { analyses, and } \\
\text { communicates } \\
\text { new knowledge, } \\
\text { methods, } \\
\text { understanding, } \\
\text { technologies, } \\
\text { materials, uses, } \\
\text { insights, beauty } \\
\text { and so forth }\end{array}$ & $\begin{array}{l}\text { Peers, } \\
\text { undergradu- } \\
\text { ate students, } \\
\text { graduate } \\
\text { Students, } \\
\text { postdoctoral, } \\
\text { Associates } \\
\text { etc. }\end{array}$ & $\begin{array}{l}\text { Teaching } \\
\text { materials and } \\
\text { methods, } \\
\text { classes, } \\
\text { curricula, } \\
\text { publications, } \\
\text { presentations, } \\
\text { exhibitions, } \\
\text { performances, } \\
\text { copyrights, } \\
\text { patents etc. }\end{array}$ & $\begin{array}{l}\text { Originality, } \\
\text { significance, } \\
\text { accuracy, } \\
\text { replicability, } \\
\text { scope, } \\
\text { applicability, } \\
\text { breadth, depth } \\
\text { and duration of } \\
\text { influence, } \\
\text { persistence of } \\
\text { influence or use, } \\
\text { adoption by } \\
\text { peers, impact or } \\
\text { public benefit } \\
\text { etc. }\end{array}$ & $\begin{array}{l}\text { Present evidence } \\
\text { that creative } \\
\text { intellectual work } \\
\text { was validated by } \\
\text { peers; } \\
\text { communicated } \\
\text { to peers and } \\
\text { broader } \\
\text { audiences; } \\
\text { recognised and } \\
\text { accepted, cited, } \\
\text { adopted or used } \\
\text { by others. In } \\
\text { other words, it } \\
\text { made a } \\
\text { difference. }\end{array}$ \\
\hline
\end{tabular}

Source: The Faculty Handbook, Iowa State University, 1998 p 12. 
122 The Lahore Journal of Economics, Vol.3, No.2

\section{References}

Baron, B., 1978. The Managerial Approach to Tertiary Education: A Critical Analysis. London: University of London, Institute of Education.

Beard, R.M.; Bligh, D. A. and Harding, A. G., 1978. Research into Teaching Methods in Higher Education. Surrey: Society for Research into Higher Education.

Everard, K. B., 1986. Staff appraisal: Lessons from industry. In Staff Appraisal: How Do We Measure Up? Coombe Lodge Report, Vol. 18, No. 18, pp 393-401.

Iowa State University, 1998. The Faculty Handbook. Ames: Iowa State University.

Greenaway, H. and Mortimer, D., 1979. Britain Polytechnics a case of rapidly evolving institutions. In Teather, D. C. B. (Ed.) Staff Development in Higher Education: An International Review and Bibliography. New York: Kogan Page.

James, C. R. and Newman, J.C., 1985. Staff appraisal schemes in comprehensive schools: A regional survey of current practice in South Midlands and South West of England. In Educational Management and Administration, 13, pp 155-164.

Kirkpatrick, D. L., 1985. How to Manage Change Effectively. London: Jossey Bass.

Turner, C.M., 1981. Appraisal Systems. Coombe Lodge Working Paper, IBN 1638 .

Zia, R., 1994. A Study to Investigate the Requirements of a Continuing Professional Development Programme for Higher Education Academic Staff in Punjab, Pakistan. Unpublished doctoral thesis submitted to the University of Wales, UK. 